\title{
Serum amyloid A protein, apolipoprotein A-I, and apolipoprotein $B$ during the course of acute myocardial infarction
}

\author{
C P J MAURY,* K J TÖTTERMAN,* C-G GREF, C EHNHOLM
}

From the * Fourth Department of Medicine, University of Helsinki, and the National Public Health Institute, Helsinki, Finland

SUMMARY Serum amyloid A protein (SAA), apolipoprotein A-I (apoA-I), apolipoprotein B (apoB) concentrations, and creatine kinase (CK)-MB isoenzyme activity were serially measured in 10 patients during the course of acute myocardial infarction. Pronounced increases in SAA concentrations were observed in all patients during infarction. The highest SAA values were observed, on average, 67 hours after the onset of chest pain. After infarction both apoA-I and apoB concentrations decreased. The reduction in apoA-I concentration 67 to 72 hours after the onset of chest pain was $(31 \%)(p<0.01)$ and the reduction in apoB concentration 55 to 60 hours after the onset of pain was $(34 \%)(p<0.01)$. Negative correlations were found between the concentrations of SAA and apoproteins A-I and B; this inverse relation was stronger between SAA and apoB than between SAA and apo-AI.

Serum amyloid A (SAA) is a low molecular weight protein $(\mathrm{Mr} \sim 12000)$ which is associated with high density lipoproteins in the circulation..$^{1-3}$ In plasma from normal subjects SAA is present only in trace amounts but in disease states characterised by tissue injury and inflammation the plasma concentration of this acute phase reactant is much increased. ${ }^{46}$ Macrophage/monocyte-derived interleukin $1^{78}$ has been shown to be a potent inducer of SAA synthesis in hepatocytes. The mechanism by which interleukin 1 stimulates the synthesis seems to be a direct modulation of the expression of the genes coding for SAA. ${ }^{9}$ A recent study suggests that tumour necrosis factor- $\alpha$ may also induce acute phase protein synthesis. ${ }^{10}$

During the acute phase state SAA comprises a substantial part of the protein component of high density lipoprotein. ${ }^{11-13}$ It is assumed that SAA associates with existing high density lipoprotein particles and causes remodelling. ${ }^{14}$ In a recent study Clifton et al showed that the presence of high concentrations of SAA was associated with phospholipid-depleted and triglyceride-enriched lipoprotein particles with a density comparable with that of normal high density lipoprotein, ${ }^{13}$ but a size larger than normal high

Accepted for publication 23 June 1988 density lipoprotein. How the association between SAA with high density lipoprotein changes lipoprotein metabolism is still unclear. Data from studies on animals are conflicting: some suggest that high density lipoprotein particles enriched with SAA are catabolised more rapidly than normal particles ${ }^{15}{ }^{16}$; in another study this was not the case. ${ }^{3}$

Myocardial infarction is associated with an acute phase response. ${ }^{17-21}$ No detailed studies on the kinetics of the SAA response or on the quantitative relation between SAA and apolipoproteins have, however, been reported in man. To address these questions we prospectively examined the SAA, apoA-I, and apoB responses to myocardial infarction and evaluated whether the changes in SAA concentrations could be correlated with the severity of myocardial injury.

\section{Patients and methods}

Ten consecutive patients admitted to the coronary care unit with acute myocardial infarction were studied (table 1). The diagnosis was confirmed by an electrocardiogram and increased creatine kinase (CK)-MB concentration in all cases. Venous blood samples were obtained from the patients on admission and then at six hourly intervals for the first 72 hours, 
Table Clinical data of 10 patients

\begin{tabular}{|c|c|c|c|c|}
\hline $\begin{array}{l}\text { Case } \\
\text { No }\end{array}$ & Age/sex & ECG result & $\begin{array}{l}\text { Peak } C K-M B \\
\text { activity }(U / l)\end{array}$ & Comments \\
\hline $\begin{array}{l}1 \\
2\end{array}$ & $\begin{array}{l}73 / F \\
77 / F\end{array}$ & $\begin{array}{l}\text { Anteroseptal transmural injury } \\
\text { Left ventricular hemiblock, } \\
\text { anterolateral iniury }\end{array}$ & $\begin{array}{r}240 \\
206\end{array}$ & $\begin{array}{l}\text { Uncomplicated recovery } \\
\text { At presentation pulmonary oedema }\end{array}$ \\
\hline $\begin{array}{l}3 \\
4\end{array}$ & $\begin{array}{l}84 / \mathrm{M} \\
66 / \mathrm{M}\end{array}$ & $\begin{array}{l}\text { Anterolateral injury, atrial fibrillation } \\
\text { Large inferoapical transmural injury }\end{array}$ & $\begin{array}{l}183 \\
370\end{array}$ & $\begin{array}{l}3 \text { months later fatal reinfarction } \\
\text { At presentation in cardiogenic shock; died on day } 7 \text {; } \\
\text { postmortem examination showed rupture of the } \\
\text { posterior left ventricular wall }\end{array}$ \\
\hline 5 & $75 / \mathbf{M}$ & Large anterolateral transmural injury & 600 & $\begin{array}{l}\text { At presentation resuscitated; died on day } 4 \text {; at } \\
\text { postmortem examination large anterior myocardial } \\
\text { infarction }\end{array}$ \\
\hline 6 & $80 / \mathrm{F}$ & $\begin{array}{l}\text { Large infero-postero-apical transmural } \\
\text { injury }\end{array}$ & 263 & Developed left ventricular failure on day 3 \\
\hline $\begin{array}{l}7 \\
8 \\
9\end{array}$ & $\begin{array}{l}50 / \mathrm{M} \\
56 / \mathrm{M} \\
72 / \mathrm{F}\end{array}$ & $\begin{array}{l}\text { Anteroseptal injury } \\
\text { Posterior injury } \\
\text { Large anteroseptal injury }\end{array}$ & $\begin{array}{l}144 \\
128 \\
254\end{array}$ & $\begin{array}{l}\text { Uneventful recovery } \\
\text { Uneventful recovery } \\
\text { In } 1974 \text { renal transplantation because of polycystic } \\
\text { kidneys; in the postinfarction period left ventricular } \\
\text { failure, immunosuppressive treatment }\end{array}$ \\
\hline 10 & $78 / \mathrm{M}$ & Left bundle branch block & 100 & $\begin{array}{l}\text { Four myocardial infarctions previously; died on day } 2 \text {, } \\
\text { postmortem examination showed fresh infarction in } \\
\text { the anterior and lateral walls }\end{array}$ \\
\hline
\end{tabular}

and subsequently daily during the patients' stay in the unit.

SAA was measured by radial immunodiffusion as described previously. ${ }^{22}$ The SAA concentration in $\mathbf{5 0}$ healthy blood donors ranged from $<1 \mathrm{mg} / \mathrm{l}$ to $15 \mathrm{mg} / \mathrm{l}^{23}$

The apoA-I and apoB concentrations were measured in a Kone C clinical analyser (Kone, Fin-

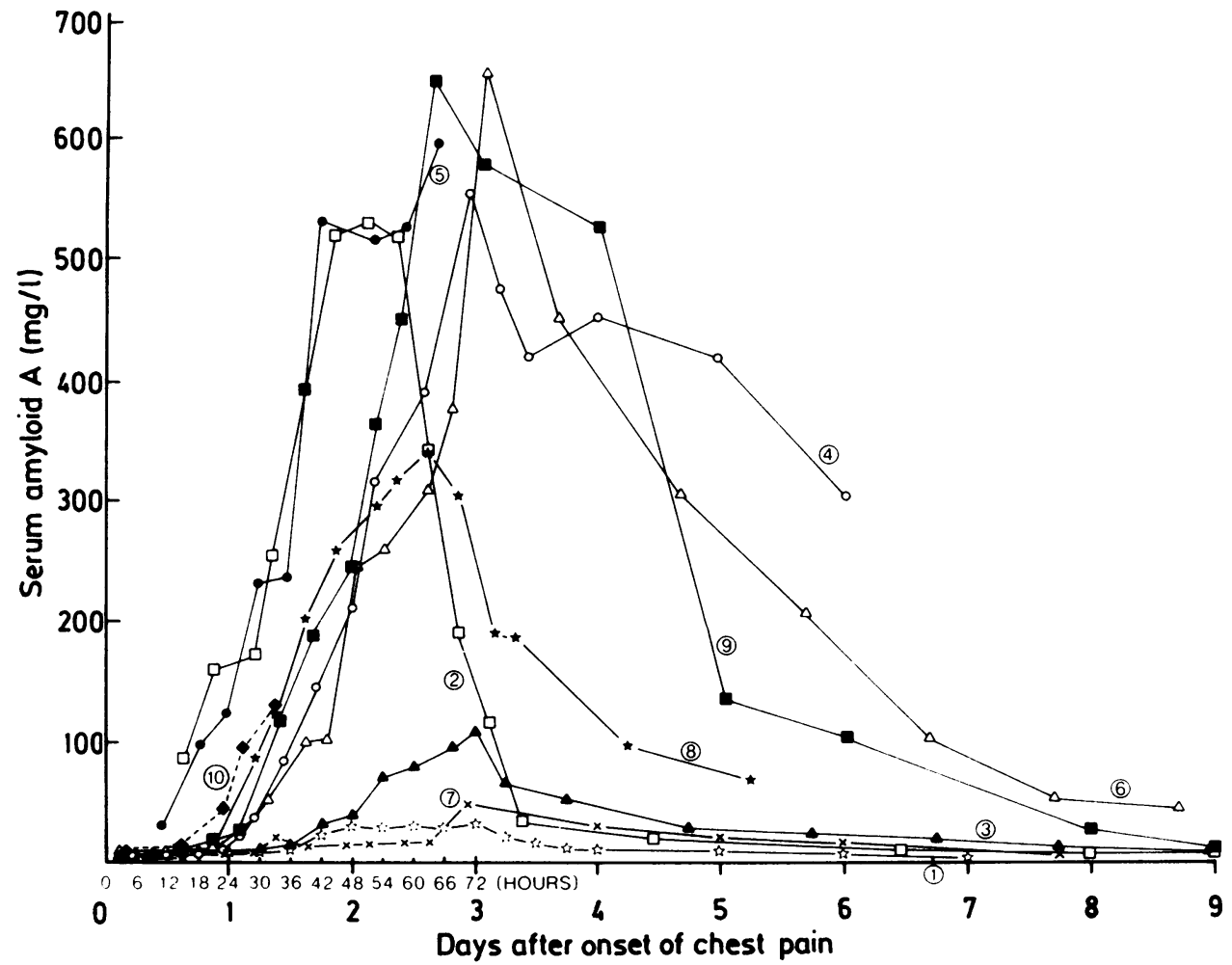

Fig 1 Individual SAA curves in 10 patients with acute myocardial infarction. Numbers refer to patients and are the same as in table 1. 


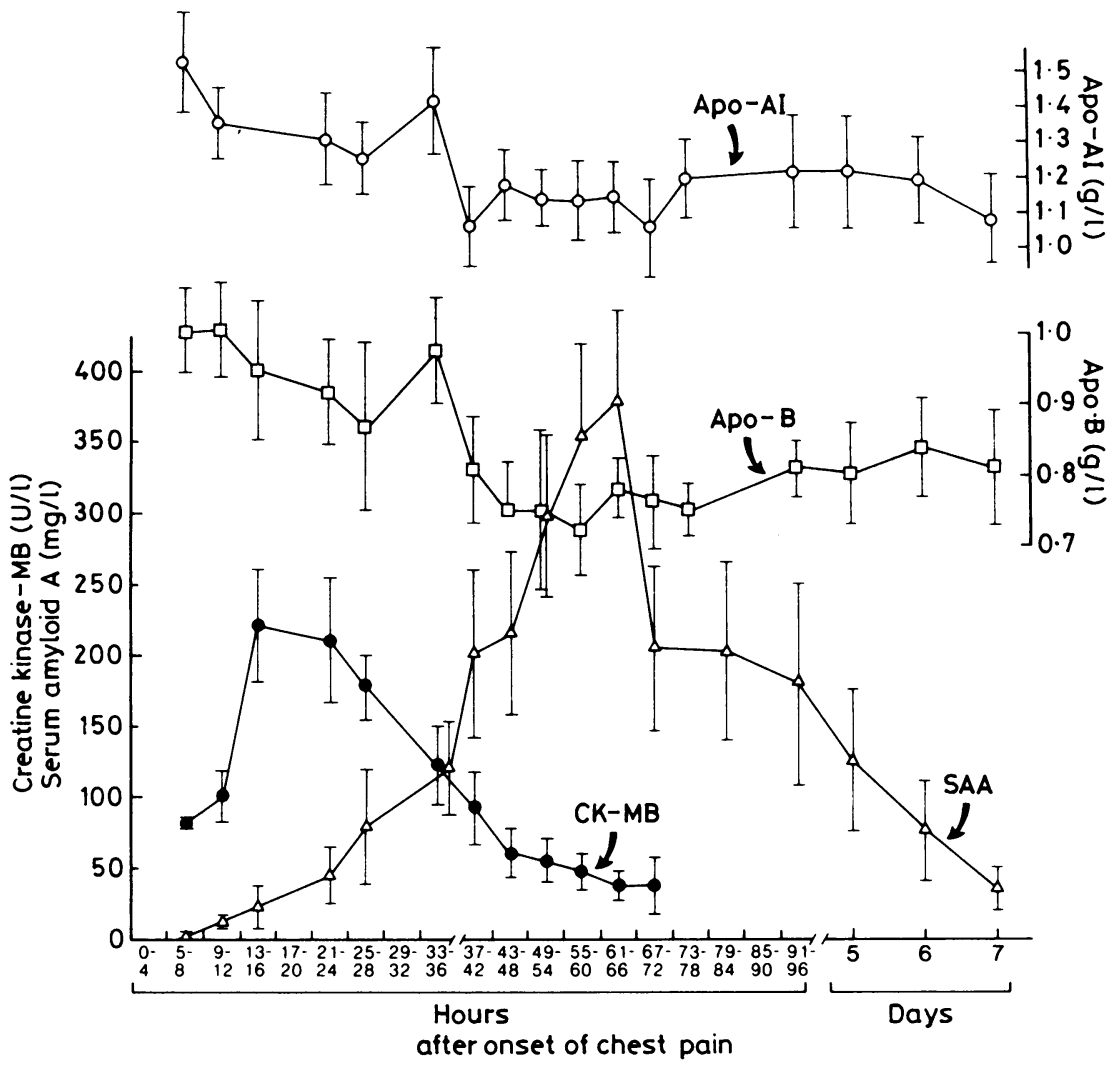

Fig 2 Summary of sequential changes in apoA-I, apoB, SAA and CK-MB concentrations in 10 infarct patients. Values are mean (SEM).

land) with a turbidometric method using the apoA-I (normal reference range $0.86-1.46 \mathrm{~g} / \mathrm{l}$ ) and apoB (normal reference range $0.92-1.33 \mathrm{~g} / \mathrm{l}$ ) kits (Orion Diagnostica, Espoo, Finland).

CK-MB activity was measured by immunoassay using a kit from Boehringer-Mannheim (Mannheim, Federal Republic of Germany).

Paired Student's $t$-test (two-tailed) and linear regression analysis (after transformation of the data to the natural logarithms) were used.

\section{Results}

Significant increases in the plasma SAA concentration occurred in all 10 patients with acute myocardial infarction (fig 1). The mean peak value of SAA concentration during infarction was 362 (SE 83) $\mathrm{mg} / \mathrm{l}$ (median $435 \mathrm{mg} / \mathrm{l}$, range 31 to $645 \mathrm{mg} / \mathrm{l}$ ). The highest SAA value was attained, on average, 67 hours (range 51 to 74 hours) after the onset of chest pain but increased concentrations were observed earlier (fig 2). The temporal relation between the kinetics of the changes in SAA concentrations and in CK-MB isoen- zyme activities in the 10 patients is summarised in fig 2 . The highest CK-MB activity could be measured about 13 to 16 hours after the onset of chest pain and thus preceded the maximal increase in SAA concentrations by about two days. A weak positive correlation ( $r=$ $0.58, \mathrm{n}=10$, NS) was found between the peak concentrations of SAA and the peak activity of CKMB during myocardial infarction; the correlation was stronger between SAA concentrations and total CKactivity $(r=0.70 ; n=10, p<0.05)$.

The concentrations of apoA-I fluctuated during the period immediately after infarction (fig 3 ). A decrease in the concentrations was, however, evident (figs 2 and 3). The mean concentrations wern lowest at 67 to 72 hours $(31 \%$ reduction, $1 \mathrm{p}<0.01 ; 95 \%$ confidence interval 0.84-1.30 g/l) after the onset of infarct pain.

The concentration of apoB showed pronounced variation during the immediate period after infarction (fig 4). A decrease in the concentrations was, however, observed (figs 2 and 4). The mean concentration was lowest at 55 to 60 hours $(34 \%$ reduction, 1 p $<0.01$; $95 \%$ confidence interval $0.60-0.85 \mathrm{~g} / \mathrm{l}$ ) after the onset of infarct pain. 


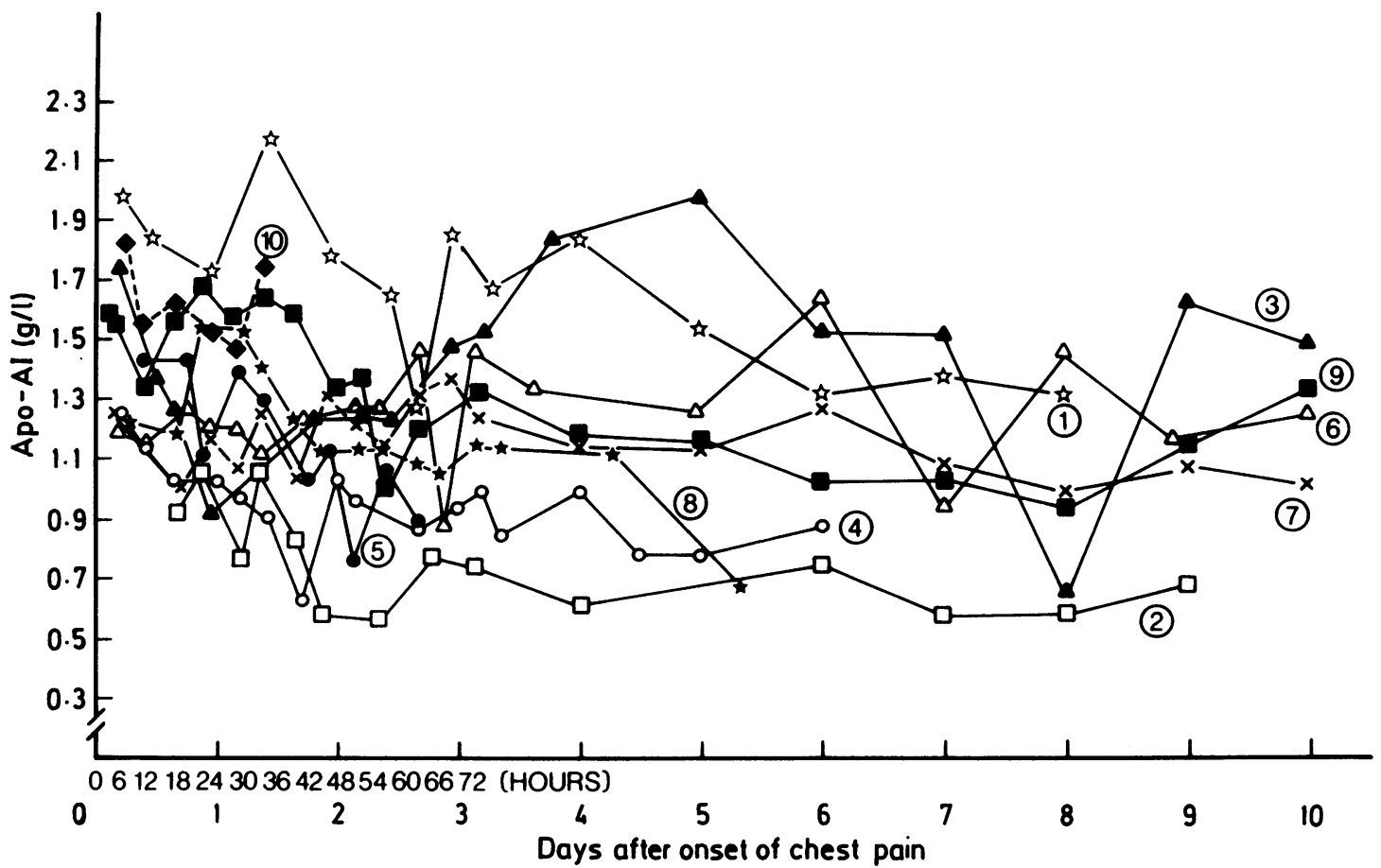

Fig 3 Individual apoA-I protein curves in 10 patients with myocardial infarction. Numbers refer to patients and are the same as in table 1 .

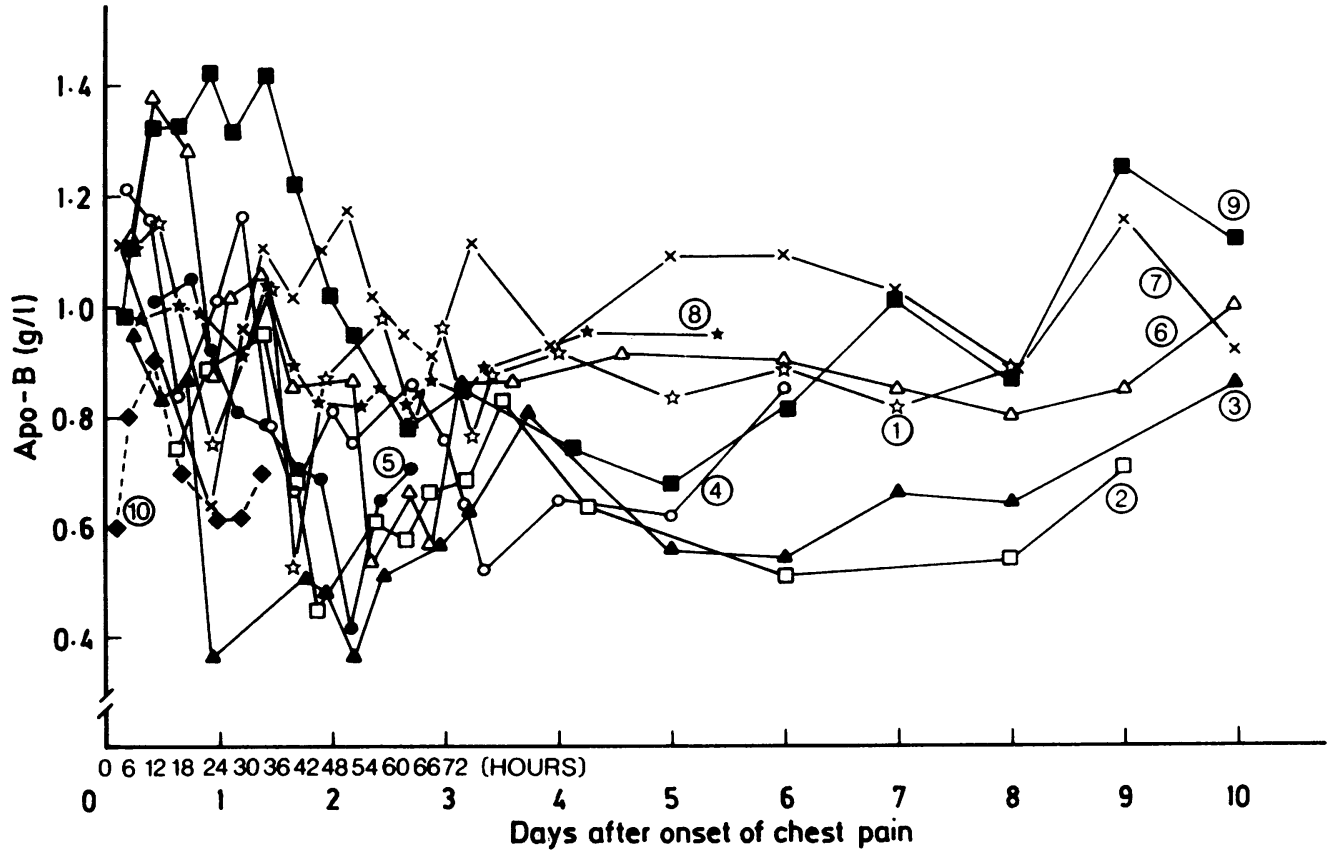

Fig 4 Individual apoB protein curves in 10 patients with myocardial infarction. Numbers refer to patients and are the same as in table 1. 
Analysis of the combined data showed an inverse correlation between the concentrations of SAA and the apolipoproteins A-I and B (fig 2). This correlation was stronger between SAA and apoB (pooled data, $n$ $=143, \mathrm{r}=-0.41, \mathrm{p}<0.001)$ than between SAA and apoA-I (pooled data, $\mathrm{n}=143, \mathrm{r}=-0.27, \mathrm{p}<0.01$ ). ApoA-I and apoB correlated positively with each other (pooled data, $n=143, r=0.33, p<0.001$ ). There were, however, pronounced individual variations in the relation between SAA and apoproteins A-I and $B$ during the course of myocardial infarction.

\section{Discussion}

These results show that acute myocardial infarction is associated with noticeable changes in the SAA, apoAI, and apoB protein concentrations associated with high density lipoprotein. During the early phase of acute myocardial infarction an inverse relation was found between SAA and apoB concentrations and also, though weaker, between SAA and apoA-I concentrations. With respect to SAA, our results agree with those of two recent reports. ${ }^{201}$

The peak SAA concentration correlated with peak total CK activity, and, to a lesser degree, with CK-MB activity, which is a fairly good index of infarct size. ${ }^{24}$ The mechanism of increase in SAA is therefore probably related to the injured myocardial tissue; cell damage and necrosis lead to the activation of monocytes/macrophages, which release soluble mediators, inducing the acute phase synthesis of SAA by the hepatocytes. Interleukin 1 has been identified as a mediator of SAA synthesis ${ }^{78}$ but other factors may also have a role. ${ }^{102526}$

In an experimental model Morrow and associates showed 500- to 2000-fold increases in mRNA for SAA during the acute phase state, ${ }^{2728}$ and a recent study suggests that interleukin 1 directly modulates acute phase gene expression. ${ }^{9}$ Although the liver is the main site of the acute phase SAA synthesis, ${ }^{782728}$ the possibility of extrahepatic synthesis should also be considered. . $^{2-31}$

In the circulation the bulk of SAA is associated with high density lipoprotein; more than $75 \%$ being associated with $\mathrm{HDL}_{3}$. During the acute phase, SAA becomes an important apolipoprotein of high density lipoprotein. When calculated as protein mass per particle, SAA may sometimes even become the major apoprotein of high density lipoprotein, which under normal conditions is apo A-I. ${ }^{1332} 33$ The acquisition of apoSAA results in the displacement of apoA-I and apoA-II from the high density lipoprotein particles. ${ }^{32}$ There is some evidence that high density lipoprotein particles enriched with SAA are more rapidly catabolised than normal particles. ${ }^{15} 16$ Our results showing an inverse relation between the circulating concentra- tions of SAA and apoA-I are of interest in this regard and are in agreement with the findings of Avogaro et $a l$, who showed reduced apoA-I concentrations during the early period after infarction. ${ }^{34}$ The decrease in apoA-I concentrations after infarction is probably due to reduced synthesis, but enhanced uptake from the circulation may also contribute.

Apolipoprotein $\mathbf{B}$ is found in low density lipoprotein, very low density lipoprotein, and chylomicrons. Most of the plasma apoB resides in low density lipoprotein and apoB is virtually the only low density lipoprotein apoprotein. Our results, showing a significant fall in circulating apoB concentration in the period immediately after infarct agree with the results of Avogaro et al $^{\beta 4}$ and Ryder et al. ${ }^{35}$

In conclusion, our results show that myocardial infarction induces pronounced changes in the plasma concentrations of SAA, apoA-I, and apoB. Further studies are therefore needed to assess the clinical relevance of these findings and to evaluate whether measurements of SAA would be of help in the assessment of prognosis and in the recognition of complications in patients with acute myocardial infarction.

We thank A-M Teppo for performing the SAA assays. This study was supported by the Sigrid Jusélius Foundation, Finland.

\section{References}

1 Benditt EP, Eriksen N. Amyloid protein SAA is associated with high density lipoprotein from human serum. Proc Natl Acad Sci 1977;74:4025-8.

2 Shore VG, Shore B, Lewis SB. Isolation and characterization of two threonine-poor apolipoproteins of human plasma high density lipoproteins. Biochemistry 1978;17:2174-9.

3 Enholm C, Teppo A-M, Ohisalo JJ, Maury CPJ. Human highdensity lipoprotein associated amyloid A protein. Structural characteristics, relation to apoA-I and A-II concentrations, and plasma clearance kinetics in the rat. Scand J Rheumatol 1985; 14:201-8.

4 de Beer FC, Mallaya RK, Fagan EA, Lanham JG, Hughes GRV, Pepys MB. Serum amyloid-A protein concentration in inflammatory diseases and its relationship to the incidence of reactive systemic amyloidosis. Lancet 1982;ii:231-3.

5 Maury CPJ. Comparative study of serum amyloid $A$ protein and C-reactive protein in disease. Clin Sci 1985;68:233-8.

6 Maury CPJ. Serum amyloid A protein: current status. Scand J Rheumatol 1984;13:97-9.

7 Selinger MJ, McAdam KPWJ, Kaplan MM, Sipe JD, Vogel SN, Rosenstreich DL. Monokine-induced synthesis of serum amyloid A protein by hepatocytes. Nature 1980;285:498-500.

8 McAdam KPWJ, Li J, Knowles J, et al. The biology of SAA: identification of the inducer, in vitro synthesis, and heterogeneity demonstrated with monoclonal antibodies. Ann NY Acad Sci 1982;389:126-36.

9 Ramadori G, Sipe JD, Dinarello CA, Mizel SB, Colten HR. Pretranslational modulation of acute phase hepatic protein synthesis by murine recombinant interleukin 1 (IL-1) and purified human IL-1. J Exp Med 1985;162:930-42.

10 Perlmutter DH, Dinarello CA, Punsal PI, Colten HR. Cachectin/ 
tumor necrosis factor regulates hepatic acute-phase gene expression. J Clin Invest 1986;78:1349-54.

11 Hoffman JS, Benditt EP. Changes in high density lipoprotein content following endotoxin administration in the mouse. Formation of serum amyloid protein-rich subfraction. $J$ Biol Chem 1982;257:10510-17.

12 Moon EA, Mackinnon AM, Barter PJ. Appearance of serum amyloid protein in high density lipoproteins of rabbits subjected to relatively mild stimuli. Biochim Biophys Acta 1984;796:354-8.

13 Clifton PM, Mackinnon AM, Barter PJ. Effects of serum amyloid A protein (SAA) on composition, size, and density of high density lipoproteins in subjects with myocardial infarction. J Lipid Res 1985;26:1389-98.

14 Coetzee GA, Strachan AF, van der Westhuyzen DR, Hoppe HC, Heenah MS, de Beer C. Serum amyloid A-containing human high density lipoprotein 3. Density, size and apolipoprotein composition. J Biol Chem 1986;261:1944-51.

15 Hoffman JS, Benditt EP. Plasma clearance kinetics of the amyloidrelated high density lipoprotein apoprotein, serum amyloid protein (apo SAA), in the mouse. J Clin Invest 1983;71:926-34.

16 Parks JS, Rudel LL. Metabolism of serum amyloid A proteins (SAA) in high density lipoproteins and chylomicrons of nonhuman primates (velvet monkey). Am J Pathol 1983;112:243-9.

17 Smith SJ, Bos G, Esseveld MR, van Eijk HG, Gerbrandy J. Acutephase proteins from the liver and enzymes from myocardial infarction: a quantitative relationship. Clin Chim Acta 1977; 81:75-85.

18 Kusher I, Broder ML, Karp D. Control of the acute phase response. Serum C-reactive protein kinetics after acute myocardial infarction. J Clin Invest 1978;61:235-41.

19 de Beer FC, Hind CRK, Fox KH, Allan RM, Maseri A, Pepys MB. Measurement of serum C-reactive protein concentration in myocardial ischaemia and infarction. Br Heart $J$ 1982;47: 239-43.

20 Marhaug G, Hårklau L, Olsen B, Husby G, Husebekk A, Wang H. Serum amyloid A protein in acute myocardial infarction. Acta Med Scand 1986;220:303-6.

21 Shainkin-Kestenbaum R, Winikoff Y, Cristal N. Serum amyloid A concentrations during the course of acute ischaemic heart disease. J Clin Pathol 1986;39:635-7.

22 Maury CPJ, Teppo A-M. Comparative study of serum amyloidrelated protein and $\beta$-2-microglobulin as markers of renal allograft rejection. Clin Nephrol 1984;22:284-92.
23 Maury CPJ, Teppo A-M, Salaspuro MP. Amyloid A fibril degrading activity in serum in liver disease: relation to serum acute phase and other protein levels. Clin Chim Acta 1983;131: 29-37.

24 Fiolet JWT, Ter Welle HF, van Capelle FJL, Lie KI. Infarct size estimation from serial CK MB determinations: peak activity and predictability. Br Heart J 1983;49:373-80.

25 Baumann H, Hill RE, Sauder DN, Jahries GP. Regulation of major acute-phase proteins by hepatocyte-stimulating factors of human squamous carcinoma cells. J Cell Biol 1986;102: $370-83$.

26 Maury CPJ, Ehnholm C, Teppo A-M. Is interferon an inducer of serum amyloid A? N Engl J Med 1983;309:1060-1.

27 Morrow JF, Stearman RS, Pelzman CG, Potter DA. Induction of hepatic synthesis of serum amyloid A protein and actin. Proc Natl Acad Sci (USA) 1981;78:4718-22.

28 Lowell CA, Stearman RS, Morrow JF. Transcriptional regulation of serum amyloid A gene expression. J Biol Chem 1986;261: 8453-61.

29 Linder E, Anders RF, Natvig JB. Connective tissue origin of the amyloid related protein SAA. $J$ Exp Med 1976;144:1336-46.

30 Rosenthal CJ, Sullivan L. Serum amyloid A: evidence for its origin in polymorphonuclear leukocytes. J Clin Invest 1978;62:1181-6.

31 Ramadori G, Sipe JD, Colten HR. Expression and regulation of the murine serum amyloid A (SAA) gene in extrahepatic sites. $J$ Immunol 1985;135:3645-7.

32 Van der Westhuyzen DR, Coetzee GA, de Beer FC. Serum amyloid A protein in plasma: characteristics of acute phase HDL. In: Marrink J, van Rijswijk MH, eds. Amyloidosis. Dordrecht: M Nijhof Publishers, 1986:115-25.

33 Bausserman LL, Herbert PN, McAdam KPWJ. Serum amyloid A polymorphism in a subject with a naturally occurring inflammatory response. Clin Chim Acta 1982;118:201-6.

34 Avogaro P, Bittolo Bon G, Gazzolato G, Quinci GB, Sparla M, Zagatti GC. Variations in apolipoproteins $B$ and A I during the course of myocardial infarction. Eur J Clin Invest 1978;8:121-9.

35 Ryder REJ, Hayes TM, Mulligan IP, Kingswood JC, Williams S, Owens DR. How soon after myocardial infarction should plasma lipid values be assessed? Br Med J 1984;289:1651-3.

Requests for reprints to: Dr C P J Maury, Senior Investigator, Finnish Academy of Sciences, Fourth Department of Medicine, Unioninkatu 38, SF-00170 Helsinki, Finland. 